\title{
SEDIMENT ORGANIC MATTER AND MAKROZOOBENTHOS ABUDANCE IN WATERS OF PURNAMA DUMAI
}

\author{
Misael Gurning ${ }^{1^{*}}$, Syahril Nedi $^{2}$, Afrizal Tanjung $^{2}$ \\ ${ }^{1}$ Student of The Faculty of Fisheries and Marine Science University of Riau, Pekanbaru \\ ${ }^{2}$ Lecturer at The Faculty of Fisheries and Marine Science University of Riau, Pekanbaru \\ *Misaelgurning97@gmail.com
}

\begin{abstract}
This research was conducted at April 2019 in Waters of Purnama Dumai. The aim of the study was to analyze the content of organic sediment and macrozoobenthos abundance and the relationship of organic sediment with macrozoobenthos abundance. The method used was a survey method consisting of 4 stations with 3 replications at each station. Sampling was carried out in the field and then taken to the Marine Chemistry Laboratory for analysis of sediment and organic material fractions. The results showed that the average content of organic sediment material in Waters of Purnama Dumai is 66,47 \% and the content of organic sediment material between different stations is not significantly different $(\mathrm{P}>0,05)$ while the abundance of macrozoobenthos is $32 \mathrm{ind} / \mathrm{m}^{2}$ and the abundance of macrozoobenthos between stations was not significantly different $(\mathrm{P}>0,05)$. The relationship between the organic matter content of sediments and the abundance of macrozoobenthos has a value $(r)=0,235797$ which means it has a weak relationship.
\end{abstract}

Keywords: Organic Material, Abundance Macrozoobenthos, Pollution

\section{PENDAHULUAN}

Kekayaan sumberdaya hayati yang tinggi. Namun demikian perairan juga sering mengalami perubahan lingkungan yang disebabkan oleh aktivitas manusia baik dari daratan maupun aktivitas yang berada di perairan laut itu sendiri. Sebagai salah satu contoh perairan yang mendapat pengaruh besar dari aktivitas daratan adalah daerah Perairan Purnama Dumai.

Lokasi Perairan Purnama Dumai secara geografis, berada pada titik koordinat 101'22'53.5872" Bujur Timur dan 1 144'1.59" Lintang Utara. Wilayah perairan ini berhadapan dengan beberapa pulau seperti Pulau Rupat, Pulau Payung, Pulau Mentele, Pulau Baru, Pulau Ketam menjadikan perairan memiliki gelombang yang kecil karena terhalang oleh daratan dan pulau-pulau tersebut (Anonim, 2012).
Perairan Purnama juga sangat berdekatan dengan kawasan industri seperti PT.Semen Padang yang tentunya memiliki output yang mengalir ke perairan laut baik material organik maupun yang anorganik serta memiliki pelabuhan yang cukup besar. Sehingga akan sangat mempengaruhi kondisi perairan terutama kandungan bahan organik.

Menurut Edward dan Tarigan (2003) bahan organik merupakan sumber makanan bagi biota laut yang pada umumnya terdapat pada dasar perairan sehingga ketergantungannya terhadap bahan organik sangat besar. Oleh sebab itu, keberadaan bahan organik penting bagi kehidupan organisme perairan termasuk makrozoobenthos.

Tujuan penelitian ini untuk mengetahui kondisi parameter perairan di 
Purnama Dumai, mengetahui kandungan bahan organik antar stasiun, mengetahui jenis/kelimpahan makrozoobenthos antar stasiun dan untuk mengetahui hubungan kandungan bahan organik sedimen dengan kelimpahan makrozoobenthos di Perairan Purnama Dumai. Adapun manfaat penelitian ini dapat memberikan informasi dan referensi penting mengenai bahan organik sedimen dan hubungannya dengankelimpahan makroozoobenthos dan dapat juga dijadikan sebagai acuan untuk penelitian berikutnya yang berkaitan dengan bahan organik dan makrozoobenthos.

\section{METODE PENELITIAN}

Penelitian ini telah dilaksanakan pada bulan April 2019 di Perairan Purnama Dumai Provinsi Riau dan dilakukan proses analisis bahan organik sedimen di Laboratorium Kimia Laut dan proses identikasi makrozoobenthos di Laboratorium Biologi Laut, Jurusan Ilmu Kelautan, Fakultas Perikanan dan Kelautan, Universitas Riau.

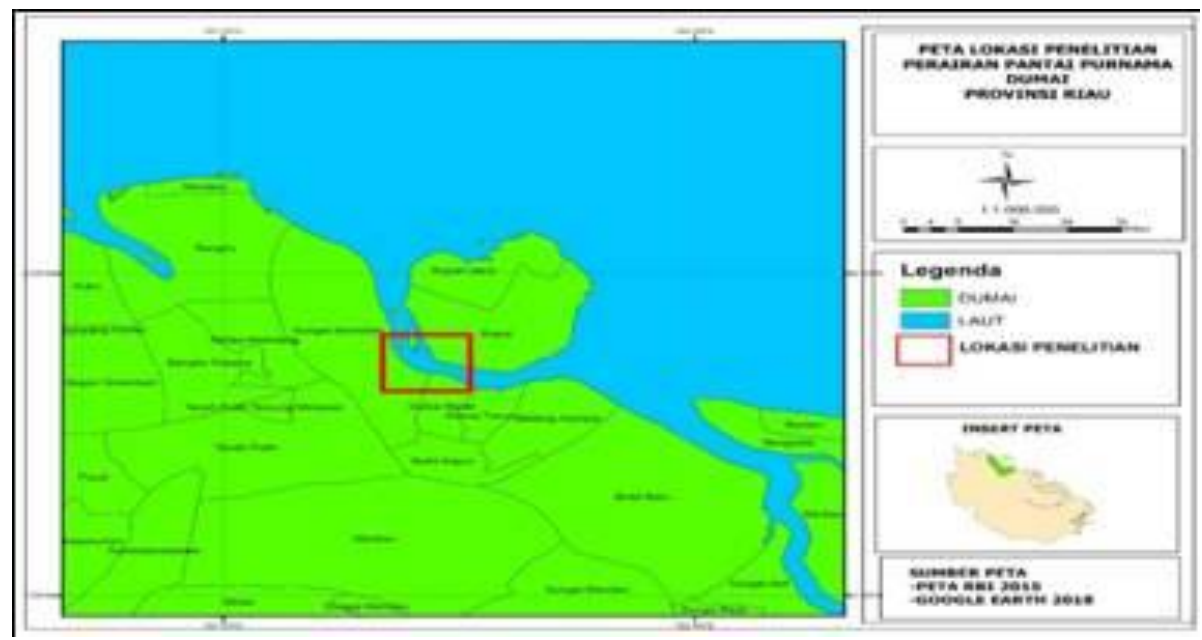

Gambar 1. Peta Lokasi Penelitian

Alat yang digunakan pada penelitian ini adalah ekman grab, furnace, ice box, kantong plastik, cawan porselin, timbangan analitik, dessicator, oven, hand refractometer, thermometer, $\mathrm{pH}$ indikator, secchi disk, current drogue, alat tulis dan ayakan makrozoobenthos. Bahan yang digunakan adalah sampel sedimen, akuades, sampel air, formalin $10 \%$ dan $\mathrm{H}_{2} \mathrm{O}_{2}$.

Metode yang digunakan pada penelitian adalah metode survey. Penentuan lokasi titik sampling dengan cara purposive sampling. Menurut Fachrul (2007), purposive sampling merupakan teknik pengambilan sampel dengan memiliki beberapa pertimbangan tertentu.

Pertimbangan yang harus diambil adalah bahwa titik sampling tersebut representatif terhadap daerah sampling pada kondisi di lapangan. Penelitian ini dibagi menjadi 4 stasiun dan tiap stasiun memiliki 3 titik sampling yang berjarak \pm $150 \mathrm{~m}$ dan untuk masing-masing titik sampling dilakukan pengulangan sebanyak 3 kali. Stasiun 1. Wilayah Industri PT.Semen, Stasiun 2. Wilayah Ekosistem Mangrove, Stasiun 3. Wilayah Pemukiman Warga, Stasiun 4. Wilayah Pelabuhan Kapal Industri.

Pengukuran parameter kualitas perairan ini dilakukan pada saat pasang. Parameter kualitas perairan yang diukur adalah bagian permukaan perairan. Parameter yang diukur pada penelitian ini adalah suhu, kecerahan, salinitas, kecepatan arus dan $\mathrm{pH}$ perairan. 
Pengambilan sampel sedimen dilakukan dengan menggunakan ekman grab ukuran $30 \mathrm{~cm}$ x $40 \mathrm{~cm}$ dengan $3 \mathrm{x}$ pengulangan untuk setiap titik sampling, sampel yang diambil dengan menggunakan spatula. Sampel sedimen dimasukkan ke dalam plastik dan diberi label kemudian dibawa ke laboratorium untuk dilakukan proses analisis. Adapun sampel yang diambil adalah seberat 500 gr berat basah kemudian diambil 150 gr untuk analisis jenis sedimen (Rifardi, 2008) dan 50 gr untuk analisis bahan organik.

Adapun pengambilan sampel makrozoobenthos itu menggunakan ekman grab $30 \mathrm{~cm}$ x $40 \mathrm{~cm}$ dengan melakukan 3x kali pengulangan untuk setiap titik samplingnya. Setelah itu sampel yang didapatkan disaring dengan menggunakan saringan berukuran $1 \mathrm{~mm}$. Sampel makrozoobenthos yang didapatkan dimasukkan pada kantong plastik dan diberi label untuk setiap stasiun lalu awetkan dengan menggunakan formalin $10 \%$. Sampel yang telah diberi larutan formalin dimasukkan ke dalam ice box.

Untuk dapat mengetahui kandungan bahan organik sedimen dihitung dengan menggunakan rumus (Odum, 1993):

Keterangan:

$$
\text { BOT }(\%)=\frac{a-c}{a-b} \times 100 \%
$$

a = berat cawan dan sampel setelah pengeringan (gram)

$\mathrm{b}=$ berat cawan (gram)

c = berat cawan dan sampel setelah pembakaran (gram)

Sampel yang telah didapat kemudian diamati dan diidentifikasi yang berpedoman pada buku identifikasi Guide to Identification of Marine and Estuarine Invertebrates oleh Gosner (1971).

Untuk mengetahui kelimpahan makrozoobenthos berdasarkan jumlah individu per satuan luas dihitung menggunakan rumus menurut (Odum, 1993).

$$
\mathrm{Di}=\frac{N}{A} \times 10.000
$$

Keterangan:

$\mathrm{Di}=$ Kelimpahan makrozoobenthos $\left(\mathrm{ind} / \mathrm{m}^{2}\right)$.

$\mathrm{N}=$ Jumlah total makrozoobenthos (individu)

$\mathrm{A}=$ Luas bukaan grab sampler $\left(\mathrm{m}^{2}\right)$

Penentuan kelimpahan relatif dihitung dengan menggunakan rumus menurut Dahuri (2003) sebagai berikut.

$$
\mathrm{KR}=\frac{\mathrm{ni}}{\mathrm{N}} \times 100 \%
$$

Keterangan :

$\mathrm{KR}=$ Kelimpahan Relatif

$\mathrm{Ni}=$ Jumlah individu jenis tertentu yang ditemukan

$\mathrm{N}$ = Jumlah total jenis-jenis yang ditemukan

Data yang diperoleh dari kelimpahan makrozoobenthos dan kandungan bahan organik sedimen dibahas secara deskriptif dan disajikan dalam bentuk tabel dan grafik. Untuk melihat perbedaan kelimpahan makrozoobenthos dan kandungan bahan organik sedimen antar stasiun penelitian dianalisis menggunakan uji Oneway ANOVA dan dilanjutkan dengan uji lanjut LSD jika terdapat perbedaan antar stasiun. Analisis dilakukan dengan bantuan Software Microsoft Excel dan Statistical Package for Social Science (SPSS) versi 16.0.

Sedangkan untuk melihat bagaimana hubungan kandungan bahan organik dengan kelimpahan makrozoobenthos dapat diketahui dengan melakukan uji regresi linear sederhana.

\section{HASIL DAN PEMBAHASAN}

Perairan Purnama Dumai termasuk wilayah Kelurahan Purnama Kecamatan Dumai Barat Kota Dumai. Secara geografis Kota Dumai berada pada titik koordinat $1^{\circ} 34^{\prime 2} 25^{\prime \prime}$ LU dan $101^{\circ} 29^{\prime} 05^{\prime \prime}$ BT. Di sebelah utara perairan Purnama Dumai terdapat beberapa pulau diantaranya, adalah Pulau Rupat, Pulau Payung, Pulau Rempang, Pulau Baru, Pulau Mantek, Pulau Mampu dan Pulau Ketam. 
Wilayah perairan Purnama Dumai dimanfaatkan oleh penduduk setempat dalam menjalankan aktivitas kehidupan sehari-hari sebagai transportasi kapal industri dan kapalkapal nelayan, sebagai daerah penangkapan ikan (fishing ground), sebagai tempat pembuangan limbah dari PT. Semen Padang serta sebagai tempat pembuangan limbah rumah tangga. Secara tidak langsung perairan
Purnama Dumai ini masih dipengaruhi oleh muara Sungai Mesjid.

Parameter lingkungan perairan diukur pada 4 stasiun dengan 3 titik sampling. Adapun parameter kualitas perairan yang diukur adalah kecerahan, suhu, salinitas, $\mathrm{pH}$ dan kecepatan arus. Hasil pengukuran lingkungan perairan dapat dilihat pada Tabel 1 .

Tabel 1. Parameter Lingkungan Perairan Purnama Dumai.

\begin{tabular}{ccccccc}
\hline Stasiun & $\begin{array}{c}\text { Titik } \\
\text { Sampling }\end{array}$ & $\begin{array}{c}\text { Kecerahan } \\
(\mathbf{m})\end{array}$ & Suhu $\left({ }^{\mathbf{0}} \mathbf{C}\right)$ & Salinitas (ppt) & $\mathbf{p H}$ & $\begin{array}{c}\text { Kecepatan Arus } \\
(\mathbf{m} / \mathbf{d})\end{array}$ \\
\hline \multirow{3}{*}{ I } & 1 & 0,10 & 34 & 23 & 5 & 0,09 \\
& 2 & 0,67 & 35 & 24,5 & 7 & 0,13 \\
& 3 & 0,80 & 32 & 25 & 6 & 0,16 \\
II & 1 & 0,17 & 33 & 22 & 6 & 0,08 \\
& 2 & 0,70 & 35 & 24 & 7 & 0,11 \\
& 3 & 0,75 & 31 & 24 & 7 & 0,31 \\
IIII & 1 & 0,20 & 33 & 22 & 7 & 0,12 \\
& 2 & 0,60 & 34 & 24 & 7 & 0,22 \\
IV & 3 & 0,70 & 32 & 25 & 7 & 0,43 \\
& 1 & 0,20 & 35 & 23 & 6 & 0,24 \\
& 2 & 1,15 & 33 & 22 & 7 & 0,43 \\
& 3 & 1,20 & 35 & 25 & 7 & 0,70 \\
\hline
\end{tabular}

Dari Hasil pengukuran parameter kualitas lingkungan perairan di Perairan Purnama Dumai dapat dikategorikan dalam kondisi yang kurang baik dilihat dari warna perairan yang cenderung coklat dan juga karena Perairan Purnama Dumai banyak menerima limbah dari berbagai aktivitas diantaranya industri, pelabuhan.

Suhu yang diukur di Perairan Purnama Dumai berkisar $(31-35){ }^{\circ} \mathrm{C}$, artinya suhu di perairan tersebut masih relatif alami walaupun telah mendekati batas ambang toleransi untuk kelangsungan hidup makrozoobenthos. Menurut Rahman (2009), suhu optimum bagi perkembangan makrozoobenthos berkisar (20-30) ${ }^{\circ} \mathrm{C}$. Suhu perairan yang lebih tinggi $(33-50){ }^{\circ} \mathrm{C}$ dapat menyebabkan terjadinya gangguan perkembangan daur hidup organisme. Nilai pH Perairan Purnama Dumai berkisar 5-7. Kisaran $\mathrm{pH}$ ini berada pada kisaran yang kurang baik. Menurut Asriani (2012), pH yang optimal untuk spesies makrozoobentos berkisar 7,0-8,5. Nilai pH yang rendah dapat meningkatkan keasaaman pada suatu perairan, sehingga menyebabkan kelimpahan makrozoobentos di perairan tersebut menjadi sedikit (Irmawan et al., 2010).

Salinitas yang terdapat di Perairan Purnama Dumai berkisar 23-25 \%o. Salinitas pada perairan tersebut masih berada pada kisaran normal. Menurut Marpaung (2013), kisaran salinitas (15-30) $\%$ masih sesuai untuk pertumbuhan makrozoobenthos.

Kecepatan arus di Perairan Purnama Dumai berkisar 0,09-0,70 m/dt. Menurut Zulfiandi (2012), kecepatan arus 0,3-0,39 $\mathrm{m} / \mathrm{dt}$ termasuk kategori sedang dan masih dibawah ambang batas bagi kehidupan makrozoobenthos.

Kecerahan di perairan ini berkisar 0,10-1,20 m. Rendahnya kecerahan di Perairan Purnama Dumai disebabkan karena adanya aliran muara sungai di 
sekitarnya yang membawa input partikel terlarut dan padatan tersuspensi yang berasal dari aktifitas domestik dan aktifitas pelabuhan di sekitar pantai, sehingga mempengaruhi kecerahan. Hal ini sesuai dengan pendapat (Sinambela et al., 2015) bahwa rendahnya kecerahan dipengaruhi oleh partikel-partikel dan sedimen yang hanyut terbawa aliran sungai dari hasil pengikisan daratan dan musim penghujan.

Hasil analisis kandungan bahan organik total sedimen pada setiap stasiun di Perairan Purnama Dumai dilihat pada Tabel 2.

Tabel 2. Kandungan Bahan Organik Sedimen di Perairan Purnama Dumai

\begin{tabular}{ccll}
\hline Stasiun & Titik Sampling & BOT (\%) & Rata-rata (\%) Standard Deviasi \\
\hline \multirow{2}{*}{$\mathbf{I}$} & 1 & 13,37 & \\
& 2 & 34,81 & $23,76 \pm 10,74$ \\
& 3 & 23,11 & \\
$\mathbf{2}$ & 1 & 3,20 & $13,65 \pm 11,07$ \\
& 2 & 12,51 & \\
& 3 & 25,25 & \\
$\mathbf{3}$ & 1 & 14,87 & \\
& 2 & 44,66 & \\
& 3 & 5,30 & \\
$\mathbf{4}$ & 1 & 6,51 & \\
& 2 & 7,40 & \\
& 3 & 6,71 & \\
\hline
\end{tabular}

Kandungan bahan organik sedimen di Perairan Purnama Dumai berkisar (6,87$23,76) \%$. Kandungan bahan organik sedimen tertinggi terdapat pada stasiun I $(23,76 \%)$, sedangkan kandungan bahan organik terendah terdapat pada stasiun IV
$(6,87 \%)$. Kandungan bahan organik sedimen pada masing-masing stasiun memiliki nilai berbeda. Persentase kandungan bahan organik sedimen pada masing-masing stasiun di Perairan Purnama Dumai dapat dilihat pada Gambar 2

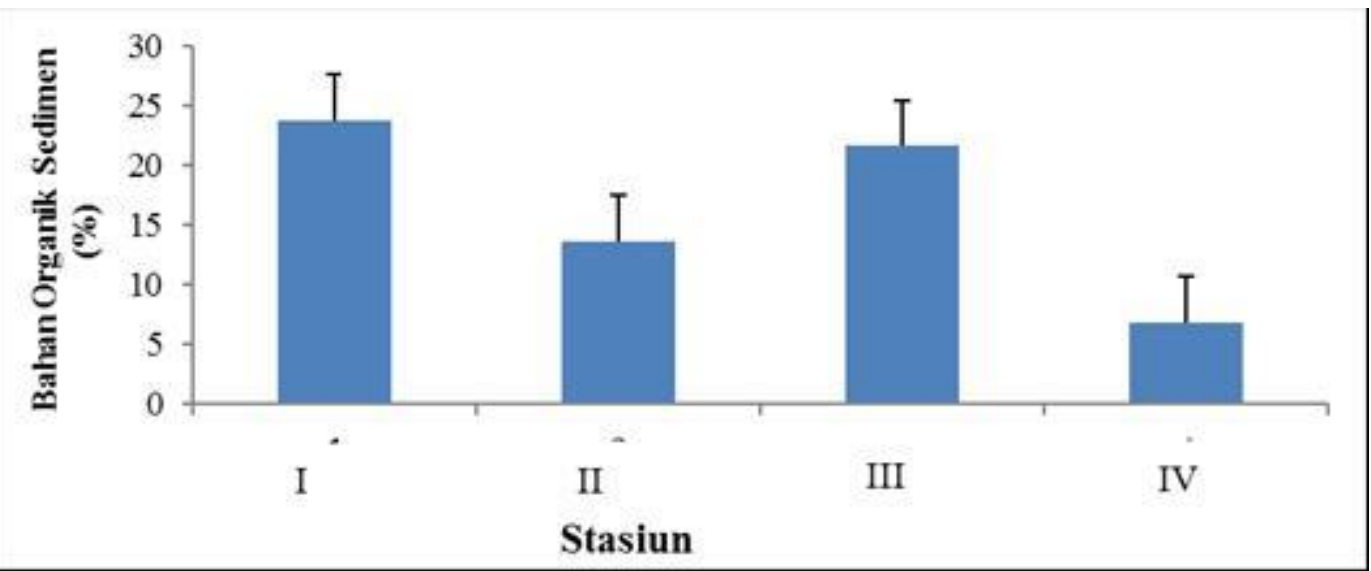

Gambar 2. Rata-rata ( \pm SD) Kandungan Bahan Organik Sedimen (\%) Antar Stasiun di Perairan Purnama Dumai 
Hasil pengukuran kandungan bahan organik di Perairan Purnama Dumai berkisar $(6,87-23,76) \%$. Kandungan bahan organik tertinggi terdapat pada stasiun I (wilayah industri PT.Semen Padang) yaitu $23,76 \%$, sedangkan bahan organik terendah terdapat pada stasiun IV (wilayah pelabuhan kapal) yaitu 6,87\%. Menurut Reynold (1971) kandungan bahan organik sedimen pada stasiun I, II dan III termasuk kriteria sedang, sedangkan pada stasiun IV termasuk kriteria sangat rendah. Kandungan bahan organik tertinggi terdapat pada stasiun I yaitu 23,76\%. Stasiun ini berada pada kawasan yang dekat dengan pabrik PT. Semen Padang. Tingginya kandungan bahan organik pada stasiun I disebabkan kawasan ini menerima masukan bahan organik dari pabrik tersebut.

Menurut Arifin (2008), kandungan bahan organik sedimen dipengaruhi oleh aktivitas atropogenik yaitu input bahan organik dari aktivitas di daratan dan perairan, selanjutnya mengendap di dasar perairan menjadi sedimen. Menurut Amin (2012), kandungan bahan organik dalam perairan akan mengalami peningkatan antara lain sebagai akibat dari limbah rumah tangga, pertanian, industri, hujan dan aliran air permukaan.

Jenis substrat berpengaruh terhadap ketersediaan bahan organik. Tingginya kandungan bahan organik ini juga disebabkan karena memiliki substrat berupa lumpur berpasir. Substrat lumpur biasanya memiliki kandungan bahan organik yang tinggi karena substrat lumpur lebih mudah mengakumulasi bahan organik. Situmorang (2008) juga berpendapat bahwa sedimen yang mengandung fraksi yang lebih halus akan mengakumulasi bahan organik jauh lebih besar dibandingkan sedimen yang mengandung fraksi lebih kasar seperti pasir dan kerikil.

Hasil identifikasi makrozoobenthos di Perairan Purnama Dumai ditemukan 12 jenis makrozoobenthos yang terdiri dari 2 kelas dapat dilihat pada Tabel 3

Tabel 3. Makrozoobenthos yang ditemukan di Perairan Purnama Dumai.

\begin{tabular}{|c|c|c|c|c|c|}
\hline \multirow{3}{*}{ Makrozoobentos } & \multicolumn{4}{|c|}{ Stasiun } & \multirow{3}{*}{ Jumlah (ind) } \\
\hline & $\mathbf{I}$ & II & III & IV & \\
\hline & \multicolumn{4}{|c|}{ Jumlah yang ditemukan } & \\
\hline Cicopreus capucinus & 8 & 10 & 11 & 2 & 31 \\
\hline Telebralia sulcata & 3 & 8 & 13 & 0 & 24 \\
\hline Lithorina undulate & 4 & 6 & 4 & 5 & 19 \\
\hline Nassarius vibra & 3 & 4 & 8 & 0 & 15 \\
\hline Cerithidea quadrata & 3 & 0 & 0 & 0 & 2 \\
\hline Anadara granusa & 2 & 2 & 7 & 1 & 12 \\
\hline Planaxis sulcatus & 1 & 1 & 0 & 0 & 2 \\
\hline Apporhais uccidentalis & 2 & 0 & 1 & 0 & 3 \\
\hline Atlanta peroni & 0 & 2 & 0 & 0 & 2 \\
\hline Natica tigrina & 0 & 4 & 5 & 2 & 11 \\
\hline Nerita polita & 0 & 6 & 5 & 4 & 15 \\
\hline Morula marginalba & 0 & 2 & 0 & 0 & 2 \\
\hline Jumlah (ind) & 26 & 45 & 54 & 14 & 138 \\
\hline
\end{tabular}

Rata-rata kelimpahan yang terdapat pada keempat stasiun berkisar (17,59$50,00) \quad \mathrm{ind} / \mathrm{m}^{2}$. Kelimpahan tertinggi terdapat pada stasiun III yaitu $50.00 \mathrm{ind} / \mathrm{m}^{2}$ dan kelimpahan terendah terdapat pada stasiun IV yaitu $17.59 \mathrm{ind} / \mathrm{m}^{2}$. Untuk kelimpahan makrozoobenthos dapat dilihat pada Tabel 4. 
Tabel 4. Kelimpahan Makrozoobenthos di Perairan Purnama Dumai.

\begin{tabular}{|c|c|c|c|c|}
\hline \multirow{3}{*}{ Stasiun } & \multicolumn{3}{|c|}{ Titik Sampling } & \multirow{3}{*}{$\begin{array}{c}\text { Rata-rata }\left(\text { ind } / \mathrm{m}^{2}\right) \\
\text { Deviasi }\end{array}$} \\
\hline & 1 & 2 & 3 & \\
\hline & \multicolumn{3}{|c|}{ Kelimpahan (ind/m²) } & \\
\hline I & 13,88 & 25,00 & 30,55 & $23,14 \pm 8,49$ \\
\hline II & 52,77 & 36,11 & 30,55 & $39,81 \pm 11,56$ \\
\hline III & 63,89 & 52,78 & 33,33 & $50,00 \pm 15,47$ \\
\hline IV & 16,66 & 16,66 & 19,44 & $17,59 \pm 1,60$ \\
\hline
\end{tabular}

Pada Tabel 3, jenis makrozoobenthos yang paling banyak ditemui di Perairan Purnama Dumai adalah dari kelas Gastropoda seperti Cicopreus capucinus, Telebralia sulcata, Lithorina undulate, Nassarius vibra, Cerithidea quadrata, Planaxis sulcatus, Apporhais uccidentalis, Natica tigrina, Nerita polita dan Morula marginalba sedangkan jenis yang lainnya adalah kelas Bivalvia. Nilai kelimpahan makrozoobenthos dari keempat stasiun di Perairan Purnama Dumai berkisar $(17,59$ $50,00)$ ind $/ \mathrm{m}^{2}$.

Kelimpahan makrozoobenthos tertinggi terdapat pada stasiun III yaitu $50,00 \mathrm{ind} / \mathrm{m}^{2}$. Tingginya kelimpahan pada stasiun ini disebabkan karena kawasan ini mempunyai substrat berupa lumpur dan tinggi kandungan bahan organik yang merupakan sumber makanan bagi makrozoobenthos. Jumlah dan laju penambahan bahan organik dalam sedimen mempunyai pengaruh yang besar terhadap populasi organisme dasar. Sedimen yang kaya akan bahan organik sering didukung dengan melimpahnya organisme benthik.

Jumlah makrozoobenthos yang ditemukan pada stasiun III sebanyak 54 individu. Hal ini terjadi karena lingkungan perairan pada stasiun ini masih terjaga dan juga banyak sumber bahan organik yang masuk ke perairan tersebut baik dari lingkungan masyarakat malalui limbah rumah tangga dan juga karena daerah ini menjadi tempat berlabuhnya kapal-kapal nelayan yang banyak meninggalkan organisme-organisme mati dari hasil tangkapan yang tidak ikut dijual. Namun apabila bahan organik terus meningkat, akan mempengaruhi oksigen terlaut pada stasiun ini. Hal ini akan mengakibatkan kehidupan makrozoobenthos akan terganggu karena oksigen terlarut yang seharusnya digunakan oleh makrozoobenthos digunakan untuk proses penguraian bahan organik. Sehingga hanya organisme yang dapat beradaptasi yang mampu bertahan hidup. Seperti Cicopreus capucinus dan Telebralia sulcata.

Kelimpahan makrozoobenthos terendah terdapat pada stasiun IV. Rendahnya kelimpahan disebabkan karena pada stasiun ini kandungan bahan organiknya rendah dan kecepatan arus lebih tinggi dari yang lainnya.

Selain itu penyebab rendahnya kelimpahan makrozoobenthos di perairan ini karena banyaknya aktivitas kapal yang berada pada stasiun ini. Pada stasiun ini banyak terjadi kegiatan bongkar muat dari kapal industri, seperti bongkar muat batu bara dan bahan kimia industri. Sementara itu pada saat proses bongkar muat sering terjadi tumpahan ke dalam perairan laut yang dapat mengakibatkan makrozoobenthos tidak dapat untuk bertahan hidup. Hal ini tentunya akan mempengaruhi kelimpahan makrozoobenthos.

Jenis substrat pada stasiun ini juga berupa pasir berlumpur dimana akan lebih sulit untuk mengakumulasi bahan organik dan akan menyebabkan rendahnya kandungan bahan organik, sehingga sumber makanan untuk makrozoobenthos juga sedikit. Hal ini sesuai dengan pendapat Situmorang (2008), yang mengatakan bahwa pada umumnya jenis sedimen 
lumpur lebih kaya akan unsur hara dari pada sedimen pasir.

Stasiun I memiliki kandungan bahan organik tinggi sedangkan stasiun ini memiliki nilai kelimpahan makrozoobenthos yang rendah yaitu 22,91 $\mathrm{ind} / \mathrm{m}^{2}$. Hal ini diduga terjadi karena dipengaruhi oleh faktor lingkungan perairan lainnya seperti BOD dan oksigen terlarut. Jika bahan organik tinggi maka oksigen yang dibutuhkan untuk menguraikan bahan organik tersebut juga tinggi, sehingga oksigen terlarut yang dapat dimanfaatkan oleh makrozoobenthos menjadi sedikit. Hal ini dapat mengganggu kehidupan organisme aerob termasuk makrozoobenthos. Musthofa (2014), menyatakan bahwa organisme yang hidup di perairan seperti makrozoobenthos sangat peka terhadap perubahan kualitas air tempat hidupnya sehingga akan berpengaruh terhadap komposisi dan kelimpahannya.

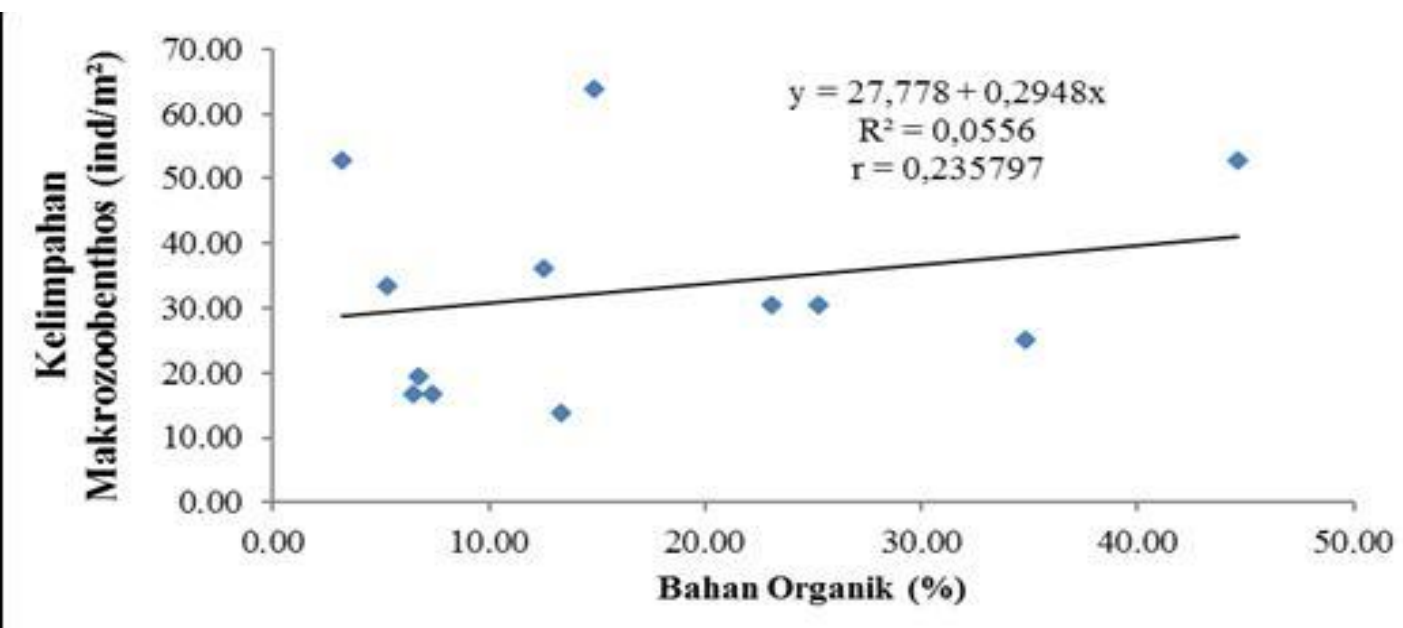

Gambar 4. Hubungan Kandungan Bahan Organik Sedimen dengan Kelimpahan Makrozoobenthos di Perairan Purnama Dumai

Berdasarkan analisis statistik, hubungan kandungan bahan organik sedimen dengan kelimpahan makrozoobenthos di Perairan Purnama Dumai adalah positif dengan koefisien korelasi (r) 0,235797. Persamaan regresinya adalah $\mathrm{Y}=27,778+0,2948 \mathrm{X}$ yang menggambarkan bahwa kandungan bahan organik sedimen dengan kelimpahan makrozoobenthos memiliki hubungan positif namun termasuk kriteria lemah di Perairan Purnama Dumai.

Berdasarkan hasil regresi, kandungan bahan organik sedimen dengan kelimpahan makrozoobenthos memiliki hubungan positif yaitu jika kandungan bahan organik sedimen tinggi maka kelimpahan makrozoobenthos juga akan tinggi. Koefisien determinasi $\left(\mathrm{R}^{2}\right)$ diperoleh
0,0556 yang berarti pengaruh kandungan bahan organik sedimen terhadap kelimpahan makrozoobenthos di Perairan Purnama Dumai hanya sebesar 5,56\% sedangkan $94,44 \%$ dipengarui oleh faktor lain seperti jenis substrat, COD, BOD, Oksigen terlarut pasang surut, kualitas perairan dan lainnya. Ulfah et al. (2012) menyatakan bahwa keberadaan hewan benthos pada suatu perairan sangat dipengaruhi oleh berbagai faktor lingkungan.

\section{KESIMPULAN DAN SARAN Kesimpulan}

Kualitas lingkungan perairan Purnama Dumai relatif kurang baik. Kandungan bahan organiknya berkisar 
berkisar 6,87-23,76 \%. Kandungan bahan organik antar stasiun tidak berbeda nyata. Kelimpahan makrozoobenthos berkisar 17,59-50,00 ind $/ \mathrm{m}^{2}$ yang mengindikasikan bahwa kelimpahan makrozoobenthos antar stasiun tidak berbeda nyata. Hubungan kandungan bahan organik sedimen dengan kelimpahan makrozoobenthos adalah posif, namun memiliki hubungan yang lemah.

\section{Saran}

Saran Perlu dilakukan penelitian lanjutan untuk mengetahui faktor lain yang mempengaruhi kelimpahan makrozoobentos di Perairan Purnama Dumai seperti jumlah kadar $\mathrm{O}_{2}$ terlarut dan BOD

\section{DAFTAR PUSTAKA}

1. Amin, B., I, Nurrachmi., dan Marwan. (2012). Kandungan Bahan Organik Sedimen dan Kelimpahan Makrozoobentos sebagai Indikator Pencemaran Perairan Pantai Tanjung Uban Kepulauan Riau. Prosiding Seminar Hasil Penelitian Dosen di Lembaga Peneltian Universitas Riau Tanggal 10 Desember 2012. Universitas Riau, Pekanbaru, 9 p.

2. Anonim, (2012), Badan Koordinasi Penanaman Modal. Kota Dumai. 2012.

3. Arifin, B. (2008). Karakteristik Sedimen ditinjau dari Aktifitas Anthropogenik di Perairan Dumai. Skripsi. Fakultas Perikanan dan Ilmu Kelautan. Universitas Riau. (p.71)

4. Edward dan M. S. Tarigan. (2003). Pengaruh Musim Terhadap Fluktuasi Kandungan Fosfat dan Nitrat di Laut Banda, Makara Sains, Volume 7(2), Pages 82-89.

5. Fachrul, M.F. (2007). Metode Sampling Bioekologi. Bumi Aksara, Jakarta.

6. Gosner, K. L. (1971). Guide to Identification of Marine and Estua rine Invertebrates. (p. 693) Curator of Zoology the Newark. New Jersey: Museum Newark.

7. Irmawan, R. N. (2010). Struktur Komunitas Makrozoobenthos di Estuaria Kuala Sugihan Provinsi Sumatra Selatan. Program Studi Kelautan FMIPA, Universitas Sriwijaya. Sumatra Selatan.

8. Odum, E.P. (1993). Dasar-dasar Ekologi. Terjemahan Tjahjono Samingan. Edisi Ketiga. Yogyakarta: Gadjah Mada University Press.

9. Rahman, F. A. (2009). Struktur Komunitas Makrozoobenthos di Perairan Estuari Sungai Brantas (Sungai Porong dan Wonokromo) . Jawa Timur. Tesis. Insititut Pertanian Bogor. Bogor.

10. Reynold, S. G. (1971). Manual Introductory Soil Science and Sample Soil Analysis Methods. North Pacific, Commission, Noumea New Caledonia.

11. Rifardi. (2008). Tekstur Sampling dan Analisis Sedimen. Pekanbaru: Unri Press.

12. Sinambela, M. dan M. Sipayung, (2015). Makrozoobenthos dengan Parameter Fisika dan Kimia di Perairan Sungai Babura Kabupaten Deli Serdang. Jurnal Biosains. Volume 1(2), Pages 44-50.

13. Situmorang, S.P. (2008). Geokimia Pb, Cr, Cu, dalam Sedimen dan Ketersediaanya pada Biota Benthik di Perairan Delta Berau, Kalimantan Timur. Skripsi. Departemen Ilmu dan Teknologi Kelautan. Fakultas Perikanan dan Ilmu Kelautan. Institut Pertanian Bogor. Bogor. 
14. Ulfah, Y. (2012). Struktur Komunitas Makrozoobenthos di Perairan WilayahMorosari Desa Bedono Kecamatan Sayung Demak. Jurnal Of Marine Research. Volume 1(2),

15. Zulfiandi., M. Zainuri dan R. Hartati. (2012). Struktur Komunitas Makrozoobenthos di Perairan Pandansari Kecamatan Sayung Kabupaten Demak. Jurnal of Marine Research. Volume 1(1), Pages 62-69 